\title{
Implementation of Audiovisual Material in an Early Sequential Bilingual Model during the Early Years'
}

\section{Implementación de material audiovisual en un modelo bilingüe secuencial temprano para la primera infancia}

\author{
Diana Carolina Durango Isaza, Clara Inés González Marín, \\ and Enrique Arias Castaño Ph.D ${ }^{2 *}$ \\ Universidad Tecnológica de Pereira, Colombia
}

\begin{abstract}
This research arose from the need to consolidate a meaningful bilingual methodology for children from three to five years of age from low socioeconomic backgrounds belonging to the public education system, where they could begin learning English and Spanish by means of a bilingual methodology that provides them with the same opportunities as middle to upper class children. Its aim is to implement an Early Sequential Bilingual Methodology Model in a public Early Childhood Development Center - ECDC (Centro de Desarrollo Infantil - CDI), and to collect data from class observations, student's responses, early childhood teachers' and English teachers' views as well as parents' perceptions towards its methodology and implementation in order to consolidate the model. Likewise, it will provide children with new opportunities to develop higher cognitive and high order thinking skills that can maximize their academic performance throughout their school years. This present Early Sequential Bilingual Model is a descriptive case study funded by a public university in Colombia and was implemented in a public ECDC (CDI) in Pereira (Risaralda-Colombia) based on the bilingual methodological proposals portrayed by Rodao (2011) and Arias et al. (2015). This research project depicts and systematizes the most predominant methodological techniques employed when teaching English at public ECDCs (CDIs) and interprets their effectiveness based on the data collected from
\end{abstract}

1 Received: December 12th 2016/Accepted: May 8th 2018

2 Diana.c.durango@utp.edu.co; claraigoma@utp.edu.co; earias@utp.edu.co 
interviews, fieldnotes and surveys. This article describes the responses of threeto five-year-old children to audiovisual material implemented in class.

Keywords: Spanish/English bilingual early childhood, early sequential bilingual methodology, reducing social gaps, equal educational opportunities, public early childhood education.

\section{Resumen}

Esta investigación surgió de la necesidad de consolidar una metodología bilingüe significativa para niños de tres a cinco años de edad, pertenecientes a niveles socioeconómicos bajos y que hacen parte del sistema de educación pública. El proyecto busca fortalecer el inglés y el español a través de una metodología bilingüe que les proporcione a estos niños las mismas oportunidades que tienen los menores de estratos medio y alto. Este estudio tiene como objetivo implementar una metodología bilingüe secuencial temprana en un Centro de Desarrollo Infantil (CDI) público, y recolectar información de observaciones de clase, respuesta de los infantes, percepciones de los educadores tanto de primera infancia como bilingües y de los padres de los niños que hicieron parte del proyecto con respecto a su implementación y su metodología para así consolidar el modelo de educación bilingüe para la primera infancia. Así mismo, se ofrecerá a los niños nuevas oportunidades para desarrollar habilidades cognitivas y neuronales que permitan maximizar su rendimiento académico durante los años escolares. Esta investigación cualitativa es un estudio de caso descriptivo financiado por una universidad pública colombiana, y fue implementado en un CDI en Pereira (Risaralda-Colombia) basado en una propuesta metodológica bilingüe presentadas por Rodao (2011) y Arias et al. (2015). Esta investigación detalla y sistematiza las técnicas metodológicas más predominantes utilizadas en la enseñanza del inglés en un CDI público e interpreta su efectividad basada en los datos recogidos en encuestas, entrevistas, y notas de campo. Este artículo describe respuestas de niños entre tres y cinco años de edad a material audiovisual implementado en clase.

Palabras claves: Primera infancia bilingüe en español/inglés, metodología bilingüe secuencial temprana, reducción de brechas sociales, igualdad de oportunidades, educación pública en primera infancia.

\section{Resumo}

Esta pesquisa surgiu da necessidade de consolidar uma metodologia bilíngue significativa para crianças de três a cinco anos de idade, pertencentes a níveis socioeconômicos baixos e que fazem parte do sistema de educação pública. O projeto busca fortalecer o inglês e o espanhol através de uma metodologia bilíngue que proporcione a estas crianças as mesmas oportunidades que têm os menores de estratos médio e alto. Este estudo tem como objetivo implementar uma metodologia bilíngue sequencial precoce em um Centro de Desenvolvimento Infantil (CDI) público, e coletar informação de observações de aula, resposta dos infantes, percepções dos educadores tanto de primeira 
infância como bilíngues e dos pais das crianças que fizeram parte do projeto com relação a sua implementação e sua metodologia, para assim consolidar o modelo de educação bilíngue para a primeira infância. Da mesma forma, oferecer-se-á às crianças novas oportunidades para desenvolver habilidades cognitivas e neuronais que maximize o seu rendimento acadêmico durante os anos escolares. Esta pesquisa qualitativa é um estudo de caso descritivo financiado por uma universidade pública colombiana, e foi implementado em um CDI em Pereira (Risaralda-Colômbia) baseado em uma proposta metodológica bilíngue presentadas por Rodao (2011) e Arias et al. (2015). Esta pesquisa detalha e sistematiza as técnicas metodológicas mais predominantes utilizadas no ensino do inglês em um CDI público e interpreta a sua efetividade baseada nos dados coletados em enquetes, entrevistas, e notas de campo. Este artigo descreve respostas de crianças entre três e cinco anos de idade a material audiovisual implementado em aula.

Palavras chaves: Primeira infância bilíngue em espanhol/inglês, metodologia bilíngue sequencial precoce, redução de brechas sociais, igualdade de oportunidades, educação pública em primeira infância 


\section{Introduction}

7 he effectiveness of audiovisual material during the implementation of an English early sequential bilingual model is one of the findings from a macro research project conducted with the aim of consolidating a bilingual education model designed for three- to five-year-old children of public early childhood development centers. This model aims to bridge the gap in the current Ministry of Education early childhood legislation and the bilingual policies in Colombia to ensure egalitarian bilingual education to all Colombian children during their preschool years, regardless their socioeconomic background.

This study was guided by the following question: What is the result of using audio visual material during the implementation of an early sequential bilingual methodology? Likewise, it had the following objective as a starting point: To describe the responses of the threeto five-year-olds, belonging to a public early childhood development center, in regard to the use of audio visual material as a teaching technique during the implementation of the early sequential bilingual methodology. Findings reveal that these kinds of materials play an important role in capturing children's attention as they create enjoyable learning environments that end up contributing to their second language acquisition process.

\section{Literature Review}

\section{Bilingual Early Childhood}

Espinosa (2010) states that the typical myth surrounding early childhood bilingualism that children acquiring two different structures and vocabulary sequentially could get them confused and overwhelmed is untrue. The author affirms that children have an innate ability to learn any type of language at any time. Hence, she declares that children should be stimulated to acquire an additional language as soon as they have a chance, since it will help them take advantage of the academic, cognitive, cultural, economic, linguistic, literacy, and social benefits of bilingualism. Ashworth and Wakefield (2005) assert that bilingual children will develop their creative thinking and problem solving skills as well as autonomy in their own language acquisition process. Along with Krashen (1981), Espinosa (2009) affirms that the teacher plays an essential role in the process of second language acquisition. Thus, early childhood professionals should strive to understand what is required 
to expose children to an additional linguistic system as well as to determine how to accomplish it following high quality methodological standards. Espinosa further explains that there are several factors that play an important role for a child to acquire a second language rapidly, such as context, children's attitude and personality, linguistic aptitude, motivation, as well as the quality and quantity of input received. Nevertheless, she affirms that the sooner children are exposed to a second language methodology the faster they will acquire it.

Ashworth and Wakefield (2005) emphasize that children are triggered by their motivation, and constant development of their cognitive and linguistic skills while interacting with others. They state that teachers could spark children's imagination and enhance their creativity by employing meaningful activities such as storytelling, singing, playing, painting, among others. In addition, teachers should pay attention to children's curiosity, praise them, as well as rough-tune their language to make it as comprehensible as possible. Furthermore, the authors affirm that when children get in contact with a new language, they commence to transfer their native language experiences to their second language as part of their acquisition development, which makes it easier to assimilate. Finally, they recommend that, during this stage, it is best to consolidate both languages and content to accelerate the learning process.

In addition, McLaughlin (1984) claims that children from two to six years of age develop their language competences through a natural acquisition process, and if they are exposed to additional linguistic systems, by the time they reach formal schooling, they will have mastered them exceptionally. The author also states that during those ages, children, driven by their curiosity, begin creating and experimenting with the new language. Additionally, she emphasizes that exposing children to an additional tongue is considered second language acquisition when children begin their process at the time when their listening and speaking skills in their mother tongue are welldeveloped.

Moreover, Titone (1972) states that children that are around four to five years old are in the best age to acquire a second language. He affirms that during this period of life, children are eager to socialize with everyone and they are curious to experiment with the language. This is because they are less inhibited in comparison to formal education students. Likewise, he emphasizes that at this age children have the capacity to imitate and assimilate specific elements of the language such as phonology, morphology, syntax, semantics, and even pragmatic and sociolinguistics aspects of the language more easily. 


\section{Early Sequential Bilingualism}

To begin with, Genesee (2009) makes a differentiation between early sequential bilingual and late sequential bilingual children. The former are children that commence acquiring a second language after having a basic command of their native language, usually during their first five years of age. The latter represents children that are exposed to a second language during their teen to adult years. Also, the author claims that since early sequential (successive) bilingual paradigms are not that popular, parents and teachers tend to be skeptical about having their children learn both language systems sequentially; nonetheless, this could be avoided by sharing the benefits and advantages of being bilingual.

Purcell, Lee, and Biffin (2006) propose three stages of early sequential bilingualism. The first one is characterized by a silent period. In this stage, children listen and observe speakers of the target language non-verbal hints. This stage could take a couple of months and teachers should allow it to happen without pressuring children since this is when they begin to understand the form of the new language. During this stage, children interpret and use body language, gestures, facial and deictic expressions to communicate and later repeat some memorized fixed phrases that they hear from their teachers. Throughout the second stage, children create their own sentences to communicate in the second language. It is essential that teachers become aware of children's language development as to provide them timely feedback, praise them, and support them along the process. Finally, in the last stage, children are able to communicate with the new linguistic code with a more accurate pronunciation, lexical and grammatical use. It is crucial to mention that during this stage, children begin switching their native language with the second language back and forth. Additionally, Purcell et al. (2006) state that this characteristic is typical of bilingual users and it helps to increase their fluency rate.

Moreover, Purcell et al. (2006), as well as Espinosa (2009), insist that teachers should find out as much information as possible about their students. Knowing their interests, needs and motivations will facilitate the design of appealing lessons according to their age, likes, experiences, and culture. Furthermore, Genesee, Paradis, and Crago (2004) affirm that teachers should not combine both language systems within sentences since students need to be exposed to the new language structure as steadily and sustained as possible in order for their sequential language acquisition process to occur. 


\section{Implementing Audiovisual Material in the Early Years}

Fernández (2014) explains that the use of audiovisual material in early education has certain advantages for language learning. First, motivation increases due to the fact that students improve their comprehension skills since they focus consciously on the language they are watching and listening. These kinds of material also motivates visual and auditory learners as they will be learning based on their learning style. A second advantage that King (cited by Fernández, 2014) points out, is that students will be exposed to authentic language. Therefore, students will improve their listening skills by the exposure to various accents and expressions.

Another benefit of implementing audiovisual material is that it helps children to create schemas of words. According to Evans and Green (as cited by Ramirez, 2013), children during the process of learning a second language make connections between what they already know and what they are learning.

In that sense, Canning-Wilson (2001) declares that the use of audiovisual material helps children to make associations between what they are watching with what they are listening to. The author also states that audiovisual material will also aid children to increase vocabulary learning as they will have an immediate image in their brain to support the language they are learning; thus, creating new schemas that help them to represent their reality.

\section{The State of the Art of Colombian Early Childhood Bilingual Models}

Little research on early childhood bilingualism have been conducted in Colombia. In the last decade, Salgado and Beltrán (2010), Rodao (2011), and Arias, Atehortúa, Chacón, Giraldo, Tamayo, Vélez, and Vidal (2015) conducted qualitative studies in this field that drew conclusions on the importance of implementing contextualized materials and meaningful activities to foster early childhood second language acquisition.

As the first point, Salgado and Beltrán (2010) carried out research in a private institution in Bogotá, in which they identified the most employed pedagogical strategies when teaching an additive bilingualism methodology to six-year-old preschoolers. Those children belonging to the middle and high socioeconomic sector that participated in the study had been exposed to this bilingual methodology for more than 2 years at the time the data were collected. The results showed the importance of 
conducting classes supported by thorough lesson planning and suitable ludic materials according to the learners' age.

Similar to Salgado and Beltrán, Rodao (2011) conducted research in Bogotá as well, where she designed and implemented a methodological proposal for three- to five-year-old children from a public early childhood development center. The author concluded that learning environments that include kinesthetic activities, arts and crafts, coloring, singing, and games foster second language acquisition. Nevertheless, in order to make these activities meaningful for children, their interests and needs must be taken into account.

On the other hand, Arias et al. (2015) proposed and implemented a simultaneous bilingual methodology in a public early childhood development center located in a rural area of Risaralda. The results showed that the acquisition of a second language occurs when being exposed to it naturally by means of ludic materials and activities.

To sum up, these studies contribute to this research as they provide insights on how early childhood bilingual education should be conducted in Colombia. Though they were carried out under divergent conditions, their implications serve as a starting point to strengthen this early sequential bilingual methodology which was designed and piloted during its first phase back in 2015. Additionally, for the sake of this project, the first investigation conducted by Salgado and Beltrán (2010) with six year olds from a private school shed light on how the socioeconomic status influences children's receptive and productive English skills given that children commence the bilingual immersion in that private institution from three years of age onwards. Subsequently, Rodao (2011) raised awareness on how children's emotional, economic, social, and political factors need to be taken into account before exposing them to bilingual education, as issues such as family care, health, nutrition, proper guidance, and even shelter may affect the implementation and their acquisition process. Lastly, Arias et al. (2015) highlights how the lack of an official early childhood curriculum for Early Childhood Development Centers in which the didactic units and syllabus could be identified makes it hard for English language teachers to align their L2 lessons to the ECDC's lessons. As a result, English teachers end up constantly inquiring the early childhood teachers for what they taught in their previous lessons in order to catch up with the first language lexicon and content presented.

All in all, being able to compare and contrast the early childhood bilingual methodologies conducted in our context enable us to acquire the necessary insights needed to conduct this research. Moreover, it 
added weight to the endeavor that the aforementioned studies have pursued in regard to the importance of standardizing an early sequential bilingual methodology, which sets the course for a future public bilingual early childhood education program for three- to five-year-old children in Colombia. This way, justice and equality could finally be spread among all ECDCs across the country.

\section{Methodology}

\section{Research Design}

The type of study selected for this research was a qualitative case study. Merriam (2009) defines it as 'an in-depth description and analysis of a bounded system' (p. 43). Interviews, surveys and observations were employed to gather information about the result of using audio visual material during the implementation of this early sequential bilingual methodology conducted with three- to five-year-old children.

\section{Context and Participants}

The context for this study was a public Early Childhood Development Center - ECDC (Centro de Desarrollo Infantil - CDI) in Pereira, Colombia. The ECDC has two branches located within the urban area whose socioeconomic strata is level 1 to 2 (very low), where 270 children from vulnerable families attend to receive integral care and education. Both branches are equipped with suitable spaces and elements to offer children integral care.

A total of 162 non-literate monolingual preschoolers were part of the implementation process during a period of four months and a half with an hourly rate of English instruction of two hours per week. The classes were directed by three English language teachers (pre-service teachers), all of them studying a bachelor's degree in English language teaching. Additionally, there were five early childhood teachers and five early childhood teaching assistants. Finally, 28 parents were also participants of the study.

\section{Data Collection Instruments}

Semi-structured interviews, surveys, and observations were the three qualitative instruments used in order to obtain information to validate this research. Two of the three semi-structured interviews were done to the five early childhood teachers and their five corresponding 
teaching assistants. Also, two online surveys were conducted through Google Forms prior to and following the implementation process. These surveys obtained information from the English teachers in regard to their perceptions, feelings, beliefs and opinions towards the early sequential bilingual methodology in place and the materials implemented. Besides, 17 observations were carried out with the aim of identifying specific elements regarding the use of materials, giving instructions, grouping, among others, as well as children's responses. (For samples, check appendices in Durango, Garzón, and Rodriguez, 2017)

\section{Data Analysis and Interpretation}

The triangulation and interpretations of the observations, surveys, and interviews were originated using the method of content analysis. After all the information was transcribed as part of the precoding process, a variety of colors were selected in order to identify the concurrent topics observed. Also, in order to ensure validity and reliability, each co-researcher corroborated the data by independently pre-coding the data. Next, they discussed their outcomes, revised them and agreed on the topics to be scrutinized, as part of testing out the system of criteria created. Subsequently, the actual coding process took place, where all the data were segregated, condensed, and coded thoroughly and comprehensively. In the coding process, the assigned codes derived from information from each of the data collection methods, when and where it took place, participants, and their role.

\section{Results and Discussion}

At the outset, the use of audiovisual materials implemented by the English language teacher helped to promote a meaningful learning environment which aided children to increase their motivation towards their second language acquisition process. Hence, during the implementation process, videos were used as pedagogical strategies to engage children, to practice the vocabulary and sentences learned in previous sessions, and to foster second language acquisition. Subsequently, the effectiveness of the strategies implemented throughout the audiovisual sessions will be analyzed and described below, as well as the impact they had according to children's responses.

Furthermore, in the following fragment extracted from an observation field note, the English pre-service teacher had already presented the vocabulary about means of transportation through 
flashcards. After reviewing the vocabulary, the teacher showed a video to engage children in the lesson and practice pronouncing various means of transport in the target language. In the video, the little ones were able to hear and identify elements such as the place, the characters, what they were saying, their actions performed, among others.

Observation excerpt one: 'There are many ways to travel' video

Ss: (Ss stared at the video, 4 Ss are dancing along)

S1: Carro (Car) - (Did car movements with his hands while watching the car in the video)

T: Car (By pointing at the video and pantomiming a car with her hands)

Ss: $i B u s !$ (Bus) (Ss replied in L1 while watching the bus in the video)

T: Bus! (T corrected pronunciation while pantomiming the bus with her hands)

T: TRAIN! (T said out loud when it appears in the video while pantomiming the train with her hands)

Ss: Train

T: Airplane (While pointing at the video and pantomiming an airplane with her hands)

Ss: Airplane Ñaann, ñañannn! (Onomatopoeic sound) (3Ss mimed an airplane by moving their extended arms up and down)

(Video finished)

Note. $\mathrm{T}=$ English pre-service teacher; $\mathrm{S} 1 / \mathrm{S} 2=$ Student 1, 2, etc.; Ss $=$ Students

In the previous sample, the English pre-service teacher was repeating all the phrases in the video while children were looking at it and repeating after the teacher. After the image of the train came up the teacher modeled by shouting 'TRAIN!' to produce a sense of excitement, to what the children said 'train'. Then the teacher said 'airplane' while pointing at the image of an airplane displayed in the video and as a result, the students repeated 'airplane' and three of them were making airplane movements with their extended arms. Moreover, the teacher pantomimed the characteristic movements and sounds of the means of transportation that appeared in the video in order for the children to correlate the words with their corresponding meaning better. While the video was playing, the teacher said the words in English out loud for the students to repeat them after her in order for them to 
practice their pronunciation. For instance, when the train appeared in the video, the teacher repeated along with her pupils the word 'train'.

To support these ideas, Mukherjee and Roy (2003) assert that employing visual aids such as videos during language lessons is a useful tool to contextualize spoken speech as it allows students to connect what is being said with what is being observed in the video. The authors advocate that students are able to understand more than $30 \%$ of what is being said with proper visual support than without it. In other words, videos are useful to enhance students' understanding of the messages conveyed thanks to all the features that can be identified in videos, such as the place, the speakers, the actions they are doing while speaking, among other elements, which enable children to comprehend the interactions in an enjoyable way.

Additionally, videos enhance children's motivation while enriching their second language acquisition. This is noted in the above observation field note sample, where one student expresses how much he liked the video by saying out loud 'otra vez' requesting the educator to play the video one more time. Also, motivation signs are also highlighted during the next early childhood teacher's interview conducted at the end of the implementation.

\section{Interview excerpt one: (Early childhood teacher one)}

'Bueno la motivación de muchos en general si fue muy buena porque todos

participaban, estuvieron muy atentos cuando la profe traía los frisos, los videos,

todos estuvieron muy atentos a lo que ella les explicaba'. ('Well the motivation of

most students in general was very good because they were participative, they were

attentive while the teacher brought out fliers containing images, and the videos, they

all were very attentive to what she was explaining'.)

Thus, this teacher implies that videos as well as other resources such as flashcards enhanced children's motivation and allowed them to participate in the sessions given that they were attentive and engaged. In other words, the use of videos triggered positive effects in terms of attention as it was evidenced during most observations, that audiovisual material allowed children to be more concentrated and to focus on the topics being studied while improving their listening skills, vocabulary, and comprehension. 
In the same fashion, videos created a fun and interesting learning environment for children on the grounds that at the end of the vocabulary presentation right before the video, as evidenced in the example above, children started to talk to each other, but as soon as the educator played it, they immediately stopped chatting and began looking at it. Subsequently, this same occurrence was corroborated by one of the English language teachers in the post-implementation survey displayed below.

\section{Survey excerpt one: (English teacher one)}

'The second technique was the use of videos as warm-ups to make students stretch

and sing in order to prepare them for the next activities of the class, these activities

were really useful because when I showed videos, the students that were not paying

attention instantly look at them'.

Hence, that English teacher expresses that she employed videos as part of her warm-up activities repertoire in order to engage students so they could focus and be prepared for the rest of the activities to come. Likewise, English language teacher one implies that videos enhanced children's attentiveness and concentration. This can be identified when she commented 'when I showed videos, the students who were not paying attention instantly look at them'. As mentioned above, videos play an essential role when hooking students back into the lessons as videos trigger students' attention and are motivating for them.

As a matter of fact, Tomalin (1991) asserts that incorporating videos into lesson plans are highly motivating for young students as they find them interesting and fun to watch. The author affirms that videos enable children to acquire words and phrases while they watch them. In other words, while engaging students back into a lesson through videos has a motivating effect on them, children are provided with the opportunity to practice words and phrases; thus, their second language acquisition process gets fostered.

Bearing this in mind, the following sample, extracted from an early childhood teacher's post implementation interview, provide further evidence on the positive impact that audiovisual materials have in terms of engagement and children's responses. 


\section{Interview excerpt two: (Early childhood teacher two)}

'A ver las que fueron más efectivas (...) eee (...) fueron los videos y las imágenes

grandes llamativas. (...) Eee (...) a los niños les (...) les llama mucho la atención

observar y como diariamente no tienen el televisor encendido, cuando se les prende $y$

es para algo didáctico ellos prestan mucha atención, así que los videos y las

imágenes grandes fueron las que más llamaron la atención'. ('Let's see, the most

effective ones $(. .$.$) eee (. .$.$) were the videos and big appealing$ images. (...) Eee (...) Observing catches

children's attention a lot and since they do not have the television on every day, when it is turned on

and if it has a pedagogical purpose they pay a lot of attention, so videos and big images were the ones

that caught more their attention'.)

In this case, the early childhood in-service teacher two recognizes the role that audiovisual materials had when acquiring English through the early childhood bilingual methodology implementation. That teacher mentions how given the fact that using a TV is not that common inside their classroom, when used for pedagogical purposes, it ends up capturing her pupils' attention. She also implies that videos big and appealing images end up making children concentrate on what is being displayed and heard. Early childhood teacher two also reports that audiovisual material was the most effective strategy used during the bilingual implementation. 'A ver las que fueron más efectivas eee fueron los videos y las imágenes grandes llamativas'. As a result, it can be inferred that videos effectively foster children's second language acquisition on the grounds that they allow them to review previously studied vocabulary and as when they are engaged they feel motivated to practice the new language presented. This was evidenced throughout the responses of children's participation while teachers were eliciting information out of images and videos.

In addition, it is important to highlight how this teacher agrees with what the early childhood teacher one previously said in regard to children being attentive in class as a result of exposure to videos. Since videos catch children's attention, it is easier for them to assimilate the new information. Following this idea, Tomalin (1991) claims that 
videos contribute significantly to the process of language acquisition and teaching since they combine education and entertainment; thus, videos stimulate children's motivation to acquire the target language. As it was mentioned before, the use of videos allowed children to easily comprehend the interactions in the second language in an entertaining way. Moreover, the use of videos as a strategy to foster second language acquisition in children played a significant role in the implementation of this early sequential bilingual methodology as they served as a tool to practice, review, and recycle vocabulary taught in previous sessions. The extract mentioned below illustrates how teachers employed videos to practice vocabulary in specific stages of the lesson to foster the language acquisition process.

\section{Observation excerpt two:}

T: Now we are going to watch a story, vamos a ver una historia que se llama

Treasure Island. ¿Cómo se llama la historia? (We are going to watch a story called...)

Ss: Treasure Island (they shouted)

T: ¿Qué van a encontrar?, ¿Qué va a encontrar Molly? (What are they going to find? What

is Molly going to find?)

Ss: ¡ Un tesoro! (A treasure!) (1S shouted the answer as well)

$\mathrm{T}$ : A treasure?

T: What is that? (2x pointing at the soil)

Ss: Potato (1 student shouted)

T: Potato (T reinstates tilting his head up and down in sign of approval)

T: ¿Qué va a encontrar él? (What is he going to find?)

Ss: Zanahoria (Carrot) (1S shouted)

T: Carrots?

Ss: (No one answered)

T: What's that? (T asked pointing at the soil)

S: Cabbage! (A student took a guess)

Ss: Onion! (All students shouted, once they saw what it was)

$\mathrm{T}$ : Onion! ( $\mathrm{x} 2$ nodding in sign of approval)

(Another explorer digs out an onion as well on the video)

Ss: Onion! (Ss shouted without the teacher asking) 
T: The teacher played 'Cho cho train' song on YouTube, kids get very enthusiastic and start singing and walking out of the room. Early childhood teacher smiled at

T's great gesture.

Note. $\mathrm{T}=$ English pre-service teacher; $\mathrm{S} 1 / \mathrm{S} 2=$ Student 1, 2, etc.;

Ss $=$ Students

The previous fragment was extracted from an observation field note where the teacher presented a video whose main character is digging some vegetables out of the ground while looking for a treasure. After the teacher introduced vocabulary of fruits and vegetables in the first stage of the session, he decided to study and practice the new vocabulary learned by playing the video. While the video was playing, the teacher elicited the name of some vegetables by asking 'What is that?' and pointing to the vegetables on the screen, to which children answer most of the time in English. For instance, when the teacher pointed to an onion on the screen and requested its name by asking 'What's that?' one student made a guess and answered 'cabbage' but when all students managed to recognize the vegetable, they shouted 'onion' in response to the teacher's question. Therefore, it can be inferred that children were able to relate the topic being studied with the mental image of it which led them to predict first the vocabulary and then identify and internalize the words due to the link made between the word and its visual representation.

Accordingly, Canning-Wilson (2001) affirms that videos serve as a tool to provide visual stimuli such as the environment which leads to prediction, speculation and activates background schemata when viewing a visual scene re-enacted. In other words, when children are provided with visual stimuli they are able to predict what is happening in the scene by connecting the language recently learned with what they are watching.

On the other hand, one of the English pre-service teachers that was part of the implementation commented on her experience of utilizing videos during her lessons.

\section{Survey excerpt two: (English teacher two)}

'During the implementation of the project I noticed that children learn more easily

when they are exposed to material like videos, songs among other sources'. 
In the above fragment of a conducted post-implementation survey, the English pre-service teacher two recognizes the usefulness of exposing children to material such as videos to enhance children's attention and foster second language acquisition. It is important to mention that most of the videos implemented in classes contained songs and chants as background music as well as appealing images. When the teacher asserts that "children are able to learn more easily when they are exposed to videos', she validates the effectiveness of employing this type of material, during the implementation of a bilingual methodology, as they strengthen the comprehension of the topics studied in the target language. The teacher also emphasizes on the fact that videos are a strategy that facilitates children's language acquisition. In other words, it makes the process of acquiring a linguistic system easier. However, as the early childhood teacher mentions during the above interview, this strategy works if employed with a pedagogical purpose.

In order to clarify this idea, it is portrayed that videos can foster second language acquisition on the grounds that they serve as a bridge to connect the language being studied with its mental representation which leads to internalization. Nonetheless, it is crucial when children get exposed to videos during their English language lessons, for teachers to interact with the videos and to ask their pupils to do the same in order for them to be more engaged and to avoid possible misbehaviors. The importance of interacting with videos is illustrated in the next sample, where an English teacher played some videos without interacting along with them which lead to misbehavior during the session.

\section{Observation excerpt three:}

T: T played 'Ears, eyes, nose and mouth' video

Ss: (Ss stared at the video. $1 \mathrm{~S}$ at front started to dance)

$\mathrm{T}$ : Played 'The numbers' video ( $\mathrm{T}$ did not engage students before playing the video)

Ss: (Most seemed to enjoy this video. They started to sing along and count with their

fingers. Some Ss at the back were not paying attention)

T: Played the video 'Move your legs'

Ss: (All students looked at the video. Some of them got up and danced and some

others danced while sitting on their chairs)

T: Played another video related to parts of the face. (T did not interact with the video) 
Ss: (Ss looked at the video. They were not asked to do anything with it. Some of them were playing with their friends)

Note. $\mathrm{T}=$ English pre-service teacher; $\mathrm{S} 1 / \mathrm{S} 2=$ Student 1, 2, etc.; Ss $=$ Students

In this case, the teacher played those videos to review vocabulary in the target language. Throughout the observation it was identified that the teacher did not engage children before playing the videos. Consequently, some students were playing and chatting while some others were staring at the video. It is clear that videos are motivating for children, but when children are not engaged before watching them, they lose their purpose, which in this particular case was to review English vocabulary. Moreover, if there are no English teacher's interactions present along the course of the video such as dancing, singing, or drilling, among others, children lose interest and begin carrying out other activities like chit chatting or playing with their classmates. In that sense, the role of the teacher is crucial when implementing audiovisual material. According to this, Santos and Osorio (2008) affirm that teachers' intervention is vital while playing videos to avoid behavioral issues during the class. In order to do so, the authors assert that the videos employed during class must have a purpose according to the stage of the lesson where they are displayed. In this way, children will be more motivated, attentive, and engaged with the video. In addition, Richert et al. (2010), found that children will acquire more vocabulary through videos when there is an intervention whether from their parents or their teachers in comparison to those who are just left unsupervised while watching them.

\section{Conclusion}

The use of strategies that enable teachers to promote second language acquisition are essential. Nonetheless, there are some implications surrounding the use of audiovisual material in the bilingual classroom, especially when concerning early childhood. To begin with, during this research children were exposed to videos by means of LCD TVs that teachers employed for specific purposes and instances of their lessons. As a result, it is essential to count with technological devices that enable teachers to display them during their implementations. Further, it was identified that English teachers must take into account children's age and needs when implementing videos, as well as their interests in order to increase their attention span during the lessons. 
Moreover, this research concluded that pedagogical tools such as audiovisual materials can be exploited either to capture children's attention and/or to control behavioral issues, or also to recycle previously learned vocabulary. Additionally, the use of contextualized and appealing audiovisual material allows children to acquire vocabulary effectively as they concentrate more on the lesson and get motivated to produce the language. In general, employing videos during early childhood bilingual education permits practicing vocabulary previously learned which leads to its internalization on the grounds that it enables children to establish connections between the vocabulary words in the target language with their visual representation.

The results also portray that when videos are implemented purposefully throughout the lesson, they are a useful strategy to acquire words and phrases in an entertaining way as children find them appealing and interesting to watch. What is more, these aspects enhance children's motivation and participation which are essential elements to enhance their acquisition process and performance due to the fact that with these type of materials they are eager to participate as they find them interesting and enjoyable. Moreover, for teachers to achieve their goals with video implementations, it is essential for them to interact along with the videos by singing, drilling, dancing, among other actions which can facilitate children's engagement and will allow them to be more concentrated and willing to watch the video to understand and learn.

In addition, language teachers can employ videos related to the lesson as warm-ups to catch children's attention and to activate prior knowledge. It was evidenced during the implementation of this project that the atmosphere of the class changed when audiovisual materials were implemented. The number of students who were interested and participated throughout the implementations significantly increased. Furthermore, English teachers should provide children with different opportunities to practice the target language, in that sense audiovisual materials become a great tool to be used in the early childhood classroom. That is to say that, the use of videos empowers the learning of new words in a fun and dynamic way.

In addition, Yazara and Arifoglu (2012) indicate that children from two to five years old have the capacity to imitate the behaviors and events they observe. They also claim the importance of presenting language considering their interests and needs since in this way learning occurs effectively, in the case of this age group they like cartoons. In that sense watching videos becomes a great tool to learn as they can 
aid comprehension and create an enjoyable learning environment, so children can learn by repetition, absorption, miming and imitation. However, the teachers' use of body language, gestures, prompting, and asking concept checking questions while playing videos, are essential to make this strategy worthwhile for young learners. Additionally, the results demonstrated that videos are useful to foster children's participation while they acquire a second language considering that children show enthusiasm while dancing, interacting, and repeating the vocabulary displayed during video time. It also shows the importance of the teacher's interaction and participation while implementing these tools.

Finally, it is important to point out that few studies have been conducted regarding early childhood bilingualism for public education in Colombia. This finding is part of the second phase of the research project directed by Enrique Arias Castaño and Clara Inés González Marín. The second phase was conducted by Durango, Garzón, and Rodríguez (2017) and its main goal is to work towards enhancing bilingual education and promoting equal bilingualism exposure during the early years, especially of the most disadvantaged Colombian children with low socioeconomic status. These kinds of projects might enhance early childhood bilingual education as they provide insights about the most suitable teaching techniques to implement while working with young language learners. 


\section{References}

Arias, E., Atehortúa, Y., Chacón, Y., Giraldo, J., Tamayo, L., Vélez, D., \& Vidal, M. (2015).

Propuesta metodológica para la primera infancia bilingüe en un centro de desarrollo infantil (Propuesta piloto). Universidad Tecnológica de Pereira.

Ashworth, M., \& Wakefield, P. (2005). Teaching the world's children: ESL for ages three to seven. English Teaching Forum, 43(1), 1-7.

Canning-Wilson, C. (2001). Visuals and language learning: Is there a connection? The Weekly Column, 48. Retrieved from https:// es.scribd.com/document/343256994/Article-48-Visuals-LanguageLearning-is-There-a-Connection-by-Christine-Canning-Wilson

Durango, D. C., Garzón, J. S., \& Rodríguez, A. I. (2017). A case study on the implementation of an early sequential bilingual methodology on three- to five-year-old children at a public early childhood development center in the city of Pereira (Undergraduate thesis). Retrieved from http://hdl.handle.net/11059/8300

Espinosa, L. (2009). Getting it right for young children from diverse backgrounds. Boston: Pearson Learning Solutions.

Espinosa, L. (2010). Children of 2020: Creating a Better Tomorrow bilingual and monolingual. In V. Washington, \& J. D. Andrews (Eds.), The importance of language and literacy development for all children (pp. 73-80). Washington DC: Children of 2020.

Evans, V. and Green, M. (2006). Cognitive Linguistics: An Introduction. Oxford University Press.

Fernandez; P. (2014). The Use of Audiovisual Stories in the Preschool CLIL Environment. (Master's thesis). Retrieved from http://digibuo.uniovi.es/dspace/bitstream/10651/28260/6/TFM Fern $\%$ C3\%A1ndez $\% 20 \mathrm{~L} \% \mathrm{C} 3 \% \mathrm{~B} 3 \mathrm{pez} \% 2 \mathrm{C} \% 20 \mathrm{Patricia}$.pdf

Genesee, F. H., Paradis, J., \& Crago, M. B. (2004). Dual language development and disorders: A handbook on bilingualism and second language learning. Baltimore, MD: Paul H Brooks Publishing.

Genesee, F. H. (2009). Early childhood Bilingualism: Perils and possibilities. Journal of Applied Research on Learning, 2 (Special Issue), 2, 1-21.

Halliwell, S. (1992). Teaching English in the primary classroom. London: Longman. 
King, J. (2002). Using DVD Feature Films in the EFL Classroom. Computer assisted language learning, 15(5), 509-523. Retrieved by http://www.moviesgrowenglish.com/PDF/CATESOL/Films for EFL,\%20J.King.pdf

Krashen, S. (1981). Second language acquisition and second language learning. Oxford, UK: Pergamon Press.

Merriam, S. B. (2009). Qualitative research: A guide to design and implementation (2nd ed.). San Francisco, CA: Jossey-Bass

Mukherjee, N., \& Roy, D. (2003). A visual context-aware multimodal system for spoken language processing. 8th European Conference on Speech Communication andTechnology - EUROSPEECH 2003. Geneva: Switzerland. doi: 10.1.1.13.9729. Retrieved from http:// www.iscaspeech.org/archive/eurospeech_2003/e03_2273.html

McLaughlin, B. (1984). Second-language acquisition in early childhood, Vol.1. Preschool children. (2nd ed.). Hillsdale, NJ: Lawrence Erlbaum Associates.

Purcell, J., Lee, M., \& Biffin, J. (2006). Supporting bilingual children in early childhood, information sheet 50. Learning Links: Helping Kids Learn. Retrieved from http://www.learninglinks.org.au/wp-content/ uploads/2012/11/LLIS-50_Bilingualism.pdf

Ramirez, M. (2013). Usage of Multimedia Visual Aids in the English Language Classroom: A Case Study at Margarita Salas Secondary School (Majadahonda) (Master's thesis, Universidad Complutense de Madrid). Retrieved from https://www.ucm.es/data/cont/docs/1192015-03-17-11.MariaRamirezGarcia2013.pdf

Richert, R. A., Robb, M. B., Fender, J. G., \& Wartella, E. (2010). Word learning from baby videos. Archives of Pediatrics \& Adolescent Medicine, 164(5), 432-437.

Rodao, E. (2011). Hacia el Diseño de una Propuesta Pedagógica para la Enseñanza de Inglés a Niños de 3 a 5 Años del Centro de Desarrollo Integral: 'Semillas de Vida' (Undergraduate thesis). Retrieved from http://hdl.handle.net/10554/5922

Rodríguez López, B., \& Varela Méndez, R. (2004). Models of teaching foreign languages to young children. Didáctica (Lengua y Literatura), 16, 163-175.

Salgado, D., \& Beltrán, D. (2010). Aprendizaje de la segunda lengua en edad preescolar: Estrategias didácticas para la enseñanza en el aula. (Undergraduate thesis). Retrieved from http://hdl.handle. net $/ 10554 / 6665$ 
Santos Miranda-Pinto, M., \& Osório, A. J. (2008). Las TIC en la primera infancia: valorización e integración en la educación inicial a través del enlace@rcacomum. Revista Iberoamericana De Educación, 46(9), 1-12. Retrieved from https://rieoei.org/RIE/article/view/1889

Titone, R. (1972). Bilinguismo precoce e educazione bilingue. Rome: Armando.

Tomalin, B. (1991) Teaching Young Children with video. In S. Stempleski, and P. Arcano, Eds.) Video in Second Language teaching: using, selecting and producing video for the classroom. Teachers of English to speakers of other languages, INC.

Yazart, T., \& Arifoglu, G. (2012). A research of audio visual educational aids on the creativity levels of 4-14 year old children as a process in primary education. Procedia - Social and Behavioral Sciences, 51, 301-306. 


\section{Authors}

*Diana Carolina Durango Isaza is currently pursuing a master's degree in Childhood at Universidad Tecnológica de Pereira (UTP), holds an English in Early Childhood specialization certificate from the British Council. Has earned her bachelor's degree in ELT from the UTP and a certificate in TEFL from the University of Maryland. She holds a virtual teacher certification from the UTP and has also worked at the Colombo Americano Pereira. She is registered as a researcher in Colciencias. Her main fields of interests are: Early childhood bilingual education, translanguaging and CLIL. She has participated in international and national conferences as a presenter.

Clara Inés González Marín holds a degree in Business administration, a bachelor's degree in Education, and a Master's degree in Linguistics. Has worked as an English teacher in different schools and institutions and currently works at the Licenciatura en Bilingüismo con énfasis en Inglés Program at Universidad Tecnológica de Pereira. Has advised and evaluated several undergraduate research projects. She belongs to the Applied Linguistics research group - POLIGLOSIA and has participated as a presenter in international and national conferences regarding early childhood bilingual education, curriculum design and renovation, cultural awareness and the development of the intercultural competence in teaching training programs.

Enrique Arias Castaño, Ph.D. is a Doctor in science in education, his dissertation is about a Dynamic Bilingual model for public schools based on the integration of language, content and translanguaging. He is currently the Dean of the Fine Arts and Humanities Faculty at Universidad Tecnológica de Pereira (UTP). Directed the bachelor's bilingual teaching program at UTP. He earned a M.A. in Applied Linguistics in ELT, with a research line in bilingualism and bilingual education. He has participated in international and national conferences as lecturer and presenter. His research interests focus on applied linguistics, language planning, bilingualism, and bilingual education. 